\title{
Biologically active pentacyclic triterpenes and their current medicine signification
}

\section{Jiř́i Patočka}

Department of Toxicology, Military Medical Academy, Hradec Králové and Department of Radiology, Faculty of Health and Social Care, University of South Bohemia, České Budějovice, Czech Republic

\begin{abstract}
Summary
Pentacyclic triterpenes are produced by arrangement of squalene epoxide. These compounds are extremely common and are found in most plants. There are at least 4000 known triterpenes. Many triterpenes occur freely but others occur as glycosides (saponins) or in special combined forms. Pentacyclic triterpenes have a wide spectrum of biological activities and some of them may be useful in medicine. The therapeutic potential of three pentacyclic triterpenes - lupeol, betuline and betulinic acid - is discussed in this paper. Betulinic acid especially is a very promising compound. This terpene seems to act by inducing apoptosis in cancer cells. Due to its apparent specificity for melanoma cells, betulinic acid seems to be a more promising anti-cancer substance than drugs like taxol.
\end{abstract}

Keywords: pentacyclic triterpene - lupeol - betuline - betulinic acid - biological activity

\section{INTRODUCTION}

Terpenes are a wide-spread group of natural compounds with considerable practical significance which are produced by arrangement of squalene epoxide in a chair-chair-chair-boat arrangement followed by condensation. In our everyday life we all encounter either directly or indirectly various terpenes, such as mono- and sesqui-terpene components of essential oils, which contribute to the aroma of plants, triterpenes of different types included in all higher plants, tetraterpene carotenoids that are abundant in our daily food, or polyterpenes, of which the most important is latex, used in the manufacture of rubbers and other rubber components. Almost all terpenes have some biological activities in animals including man and also play a meaningful role in human medicine. From this point of view the most important group of terpenes are triterpenes, triterpene glycosides, (also known as saponines), and other triterpenoids, representing one of numerous classes of natural compounds. They serve as secondary metabolites of mixed biosynthesis, like alkaloids, flavonoids, oligosaccharides etc. There is a growing interest in natural triterpenoids caused as much by the scientific aspects of extraction and structural analysis of these compounds, as by the fact of their wide spectrum of biological activities; they are bactericidal, fungicidal, antiviral, cytotoxic, analgetic, anticancer, spermicidal, cardiovascular, antiallergic and so on In recent years, a considerable number of studies conducted in many scientific centres have been devoted to the three compounds of this group, especially: lupeol, betulin and betulinic acid. These compounds are the main object of this article.

\section{COMMON CHEMICAL STRUCTURES OF TRITERPENES}

Triterpenes comprise a large number of different types of compounds which may be divided into more important chemical structure families. The main groups of triterpenoids and their glycosides are represented by tetracyclic derivatives of protostane, cycloartane, dammarane, euphane, and pentacyclic derivatives of ursane, gammacerane, lupane, and hopane (Fig. 1a). 
<smiles>CC1C2C3CCC4C(CCC5C(C)(C)CCCC45C)[C@@]3(C)CCC2(C)CC[C@@H]1C</smiles>

URSANE (I)

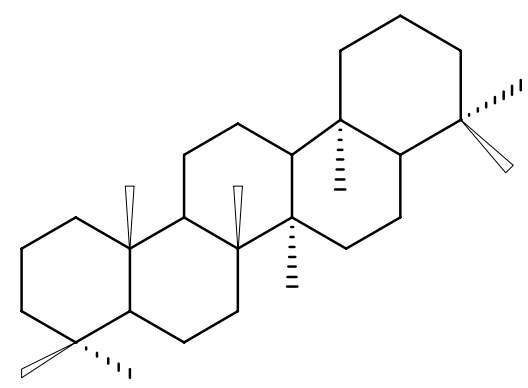

GAMMACERANE (II)<smiles></smiles>

LUPANE (III)<smiles>CC(C)C1CCC2(C)C1CC[C@]1(C)C3CCC4CCCC(C)(C)C4(C)C3CCC21</smiles>

HOPANE (IV)<smiles>CC(C)C1CC[C@]2(CO)CC[C@]3(C)C(CCC4C5(C)CCC(O)C(C)(C)C5CCC43C)C12</smiles>

BETULIN (V)<smiles>C=C(C)C1CCC2(C(=O)O)CC[C@]3(C)C(CCC4C3CCC3C(C)(C)C(O)CCC43C)C12</smiles>

BETULINIC ACID (VI)<smiles>CC(C)C1CCC23CCC4(C)C(CCC5C(C)(C)C(O)CCC54C)C2(C)CCC1C3C</smiles>

LUPEOL (VII)

Fig. 1b. Pentacyclic triterpenes: betuline, betulinic acid, lupeol 
Pentacyclic triterpenes are all based on a 30-carbon skeleton comprising five six-membered rings (ursanes and lanostanes) or four six-membered rings and one five-membered ring (lupanes and hopanes). In the chemical literature, both lupanes and hopanes are sometimes referred to by the ambiguous term, steroid triterpenes. Among the afore-mentioned compounds, betulin (betulinol) (Fig. 1b, V) is the most abundant in nature. It is also a precursor in the biosynthesis of the most biologically potent compound belonging to this group - betulinic acid (Fig. 1b, VI). Betulin was one of the first natural products to be isolated from plants as a pure chemical substance. It was isolated by Lowitz in 1788 by sublimation from birch bark and this technology is used even now. The chemical structure of betulin was completely clarified in 1952. In later years this compound was to be found in other plant species of the Betulaceae family, i.e. the bark of hazel (Corylus avellana), hornbeam (Carpinus betulus) and of a number of Alnus species. The content of betulin in birch bark varies between 10 and $30 \%$. It is found mainly as crystalline deposits in the outer layers of the bark, consisting of large cells with thin walls, which are formed in spring. The white color of birch bark is attributed to betulin, which often fills almost the entire interior of the peridermal cells. Betulin can be isolated from birch bark either by sublimation or by extraction with organic solvents (chloroform, dichloromethane, acetone, ethanol and others) followed by the appropriate solvent. This compound is the principal component of birch bark but it is usually accompanied by trace amounts of lupeol (Fig. 1b, VII), betulinic acid, betulinic aldehyde and allobetulin. Betulin, as well as its semi-synthetic ester derivatives (tartate, phthalate, tetrachlorophthalate), are excellent emulsifiers for oil/water systems.

Betulin is a valuable component of cosmetic powders and other cosmetic products. The pure compound as well as birch bark extract may be used in hair conditioners and as additives in the production of shampoo. In Finland, where considerable amounts of birch bark waste are obtainable from the wood industry (200,000 tons/year $=2,500$ tons of $95 \%$ betulin), intensive research is being conducted on the utilization of betulin as a precursor in the manufacture of colophonium lacquers, and first-rate protective coatings with high water-, chemical- and biological resistance.

The esters of betulin and fatty acids can be utilized in the production of cosmetics and as plasticizers for PVC. Attempts have been made to polymerize betulin with ethylene oxide and succinic acid and then to further esterify the obtained product with polyethylene glycol. The reaction of betulin with polyisocyanate has yielded polyurethane compounds that are thermo stable and has shown very good plastic properties.

No less interesting are the biological activities of pentacyclic triterpenes. In recent years, many research centres have concentrated their studies on the biological activity of lupane derivatives, and especially on the anti-inflammatory, anticancer and antiviral properties of these compounds. The experiments conducted using various pharmacological models have revealed that most of these compounds exert a significant anti-inflammatory action. The search for the anti-inflammatory activity was encouraged by reports of the potent anti-inflammatory action of many free and sugar-bound triterpenes, such as oleanolic acid and its glycosides isolated from marigold (Calendula officinalis) (Szakiel et al. 1995), escin from horsechestnut (Aesculus hippocastanum) (Sirtori 2001) or glycyrrhizin from licorice (Glycyrrhiza glabra) (Olukoga and Donaldson 2000).

\section{LUPEOL}

The toxicity of lupeol is very low. Lupeol administered orally in a dose of $2 \mathrm{~g} / \mathrm{kg}$ produced no adverse effects in rats and mice, and after 96 hours of observation no mortality was recorded. Lupeol administered orally or intraperitoneally in a dose of $25-200 \mathrm{mg} / \mathrm{kg}$ showed anti-inflammatory action in acute and chronic inflammation in rats and mice (Geetha and Varalaxmi 1998). The highest activity p.o. was noted in a carageenin-induced edema. A marked antiinflammatory action was also demonstrated in a model of chronic arthritis where the effect observed was comparable to that of acetylsalicylic acid in a dose of $100 \mathrm{mg} / \mathrm{kg}$. Anti-inflammatory activity was confirmed in tests on both rats and mice. In formaldehydeinduced arthritis in rats, lupeol was found to be active in a dose comparable to acetylsalicylic acid. Similarly to other anti-inflammatory agents, lupeol significantly reduced the exudate volume and the total leukocyte count. Reduction in the exudate volume (by $32 \%$ ) after lupeol $(200 \mathrm{mg} / \mathrm{kg})$ was also observed in the acetic acid-induced vascular permeability test in mice. Also, 3-O-acyl-derivatives of lupeol have anti-inflammatory properties and many of them are present in different medicinal plants, as are lupeol acetate and lupeol docosanoylate in Willughbeia firma (Subhadhirasakul et al. 2000), lupeol linoleate isolated from Crateava nurvala (Geetha and Varalaxmi 1998) or lupeol linoleate and lupeol palmitane present in the bark of roots of Alstonia bornei. Lupeol is a competitive inhibitor of both trypsin and chymotrypsin $\left(\mathrm{K}_{\mathrm{i}}\right.$ values 22 and $8 \mu \mathrm{M}$, respectively) (Rajic et al. 2000).

Lupeol failed to show any analgesic or antipyretic effect, but on the other hand, it did not induce a gastric ulcer. These observations suggest that lupeol acts via a different mechanism of action than acetylsalicylic acid, and so it does not inhibit cyclooxygenase activity and the synthesis of prostaglandins (Kweifio-Okai et al. 1995). It was hypothesized that the activity of this 
pentacyclic triterpene may be due to an immunosuppresive action and the inhibition of cell migration to the inflammation site as well as to a reduction in the release of pro-inflammatory chemotactic factors (Fernandez et al. 2001). Lupeol is the major of a bioactive fraction with feeding deterrency and/or growth-disrupting effects against some insectual pests in some plants, for example in Senecio heritieri (González-Coloma et al. 1999).

\section{BETULIN}

Betulin is a constituent of the cork layer of the outer bark of Betula alba, B. pendula, B. pubescent and B. platyphylla. Other sources are Diospyros leucomelas, Nelumbo nucifera, Zizyphus mauritiana and seeds of Ziziphus vulgaris var. spinosus. Betulin also occurs as the palmitate in the glue firm bark of Trochodendron aralioides.The antiphlogistic activity of betulin was confirmed in various experimental models. Studies on the activity of a methanolic extract from the rhizomes of $N$. nucifera, as well as betulin and betulinic acid revealed a marked inhibition of the carrageenin- and serotonin-induced rat paw edema, which was comparable to that of the standard anti-inflammatory agents phenylbutazone and dexamethazone. The authors of these studies concluded that lupane derivatives (steroid triterpenes), have an affinity for glucocorticoid receptors. This mechanism of action was confirmed by another study on three triterpenes isolated from D. leucomelas: betulin, betulic acid (Recio et al. 1995) oleanolic (Singh et al. 1992) and ursolic acid (Najid et al. 1992). All triterpenes tested showed anti-inflammatory activity in the following model tests: serotonin -, cararrageenan-induced paw edema; and TPA- and EPP-induced eye edema. Administration of progesterone, actinomycine $\mathrm{D}$ and cycloheximide helped to clarify a glucocorticoidal mechanism of action for the compounds tested, and among which betulinic acid showed the highest activity (Recio et al. 1995).

\section{BETULINIC ACID}

Betulinic acid is found in many plant species. Its content, however, is low. Menyanthes trifoliata, a bog plant, is the rare exception (Huang et al. 1995). Its underground parts contain marked amounts of free betulinic acid and triterpene saponines with betulinic acid as the aglycone. Betulinic acid was found in almond hulls (Takeoka et al. 2000) and also in other biological sources. Betulinic acid is a potent antiphlogistic agent acting via inhibition of the enzymes in the arachidonic acid pathway. Current experimental data and attempts to elucidate the exact mechanism for the anti-inflammatory action of lupane derivatives have provided contradictory results and so further studies are needed.

During the past several years almost 3000 plant extracts have been investigated for antitumor activity and in these studies, which were conducted under the auspices of the National Cancer Institute (NCI), USA, have revealed that betulinic acid may be considered a potential anti-cancer agent. In experiments betulinic acid was selective against neuroblastoma cells and lacked side-effects (Schmidt et al. 1997; Fulda et al. 1998). The cytotoxic activity of betulinic acid was tested on more human melanoma cell lines, and a significant inhibition of cell growth was observed (Selzer et al. 2000). The compound was also tested in mice infected with human melanoma (Pisha et al. 1995). The growth of the tumor was observed for 40 days. Betulinic acid was shown to be responsible for a marked reduction of tumor mass and did not induce any side effects such as weight loss.

The antitumor-activity of betulinic acid is strongly selective against human melanoma cells (Selzer et al. 2000). In the studies conducted on other types of cancer cells it was proven to be inactive, except against melanoma and neuroblastoma cells (Fulda et al. 1999). As is generally acknowledged, betulinic acid induces apoptosis that is the controlled death of a cancer cell. Being selective towards melanoma cells it does not affect normal cells (Zuco et al. 2002). This feature makes betulinic acid unique in comparison to compounds that are currently used in cancer therapy, such as taxol, camptothecin, elipticine, etoposide, vinblastine or vincristine and so on. All these antitumor-compounds are very toxic and inhibit replication of both cancer and normal cells. However, despite their toxicity, they are used today in chemotherapy as the drugs of choice.

Elucidation of the exact molecular mechanism of the action of betulinic acid is still unknown and it is a subject for very intensive research (Salti et al. 2001). In the last five years more papers dealing with the antimelanoma activity of betulinic acid have been published. From the point of view of current human melanoma therapy it is worth noting that betulinic acid is not cytotoxic to normal cells (at $\mathrm{pH}>$ or $=7$ ) even after a 48 hour exposure, but it does exert a cytotoxic effect on cancer cells at a $\mathrm{pH}$ that is typical for them $(\mathrm{pH}<$ or $=6.8)$ and therefore qualifies as a potential anticancer drug. Taking into account its lack of toxicity towards normal cells and high antitumor activity it may be expected that betulinic acid will be shortly accepted as a candidate for adjuvant therapy in the treatment of human melanoma (Rieber et al. 1998; Zuco et al. 2002)

Betulinic acid and its derivatives have been discovered as a new class of compounds that seem to protect the cells of human immunological system in 
vitro from attack by the HIV virus (Soler et al. 1996). Synthetic betulinic acid derivatives, especially 3alkylamido-3-deoxy-betulinic acid derivatives, inhibit the life cycle of the virus in the infected cells in its early phase, and thus defend the surrounding cells from HIV proliferation (Kashiwada et al. 2000). The exact mechanism of this action still remains unclear. It is very probable that betulinic acid derivatives combine with the protein coat of the virus and thus hinder its binding to the cellular membrane of the host cell. Unbound virus is incapable of reproduction.

The antiviral properties of betulinic acid were also confirmed in clinical trials (De Clercq 2000). Until now only monoclonal antibodies and peptides have been reported to inhibit HIV's attachment to the membranes of the host cell. A group of Japanese scientists has confirmed that betulinic and also some other triterpenoide acids inhibit HIV 1 replication (Ma et al. 1999). In order to elucidate which structural elements were responsible for the antiviral activity, other derivatives were tested (Kanamoto et al. 2001) . Dihydrobetulinic acid was found to be the most potent HIV replication inhibitor (Kashiwada et al. 1996; Hashimoto et al. 1997).

\section{OTHER PERSPECTIVE PENTACYCLIC TRITERPENES}

Very strong cytotoxic activity has also been shown in some other pentacyclic triterpenes foe example ursolic acid (Novotny et al. 2001), produced by a number of plant species, e.g. Prunella vulgaris Vaccinium macrocarpon), Actossaphylos uva-ursi, Malus spp., Pyrus spp. etc., bacteriohopane-32-ol from bacteria Rhodopseudomonas palustris (Nagumo et al. 1991), some lanostane-type cytotoxic active triterpenes, called ganoderic acids were isolated from the spores of the mushroom Ganoderma lucidum (Min et al. 2000) together with other types of inflammatory active triterpenoids from this very old and mysterious Chinese mushroom (Patočka 1999), triterpenoid saponins of oleane type from some Brazilian plants with antiviral activity (Simoes et al. 1999) and many others.

\section{REFERENCES}

De Clercq E.: Novel compounds in preclinical/early clinical development for the treatment of HIV infections. Rev Med Virol 10:255-277. 2000; Erratum in: Rev Med Virol 10:349, 2000.

Fernandez M.A., B. de las Heras, M.D.Garcia M.T.Saenz, A.Villar: New insights into the mechanism of action of the anti-inflammatory triterpene lupeol. J Pharm Pharmacol 53:1533-1539, 2001.
Fulda S., I. Jeremias, H.H.Steiner, T.Pietsch, K.M.Debatin: Betulinic acid: a new cytotoxic agent against malignant brain-tumor cells. Int J Cancer 82:435-441, 1999.

Fulda S., S.A.Susin, G.Kroemer, K.M.Debatin: Molecular ordering of apoptosis induced by anticancer drugs in neuroblastoma cells. Cancer Res 58:4453-4460, 1999.

Geetha T., P. Varalaxmi: Anti-inflammatory activity of lupeol and lupeol linoleate in adjuvant-induced arthritis. Fitoterapia 69: 13-19, 1998.

González-Coloma A., M. Reina, B.M.Frga, C.Gutiérrez, C.L.Balboa: Bioactive Lupeol from Senecio heritieri structure - activity relationship. Conference of the International Society of Chemical Ecology, Marseille 1999; Abstract p. 44.

Hashimoto F., Y. Kashiwada, L.M.Cosentino, C.H.Chen, P.E.Garrett, K.H.Lee: Anti-AIDS agents - XXVII. Synthesis and anti-HIV activity of betulinic acid and dihydrobetulinic acid derivatives. Bioorg Med Chem 5:2133-2143, 1997.

Huang C., H. Tunon, L. Bohlin: Anti-inflammatory compounds isolated from Menyanthes trifoliata L. Yao Xue Xue Bao 30:621-626, 1995.

Kanamoto T., Y. Kashiwada, K. Kanbara, K. Gotoh, M. Yoshimori, T. Goto, K. Sano, H. Nakashima: Antihuman immunodeficiency virus activity of YK-FH312 (a betulinic acid derivative), a novel compound blocking viral maturation. Antimicrob Agents Chemother 45:1225-1230, 2001.

Kashiwada Y., J. Chiyo, Y. Ikeshiro, T. Nagao, H. Okabe, L.M.Cosentino, K.Fowke, S.L.Morris-Natschke, K.H.Lee: Synthesis and anti-HIV activity of 3alkylamido-3-deoxy-betulinic acid derivatives. Chem Pharm Bull (Tokyo) 48:1387-1390, 2000.

Kashiwada Y., F. Hashimoto, L.M.Cosentino, C.H.Chen, P.E.Garrett, K.H.Lee: Betulinic acid and dihydrobetulinic acid derivatives as potent anti-HIV agents. J Med Chem 39:1016-1017, 1996.

Kweifio-Okai G., F. de Munk., T.A. Macrides., P. Smith, B.A. Rumble: Anti-arthritic mechanisms of Lupeol Triterpenes. Drug Develop Research 36: 20-24, 1995.

Ma C., N. Nakamura, H. Miyashiro, M. Hattori, K. Shimotohno: Inhibitory effects of constituents from Cynomorium songaricum and related triterpene derivatives on HIV-1 protease. Chem Pharm Bull (Tokyo) 47:141-145, 1999.

Min B.S., J.J.Gao, N.Nakamura, M.Hattori: Triterpenes from the spores of Ganoderma lucidum and their cytotoxicity against meth-A and LLC tumor cells. Chem Pharm Bull (Tokyo) 48:1026-1033, 2001.

Nagumo A., K.Takanashi, H.Hojo, Y.Suzuki: Cytotoxicity of bacteriohopane-32-ol against mouse leukemia L1210 and P388 cells in vitro. Toxicol Lett 58:309-313, 2001.

Najid A., A.Simon, J.Cook, H.Chable-Rabinovitch, C.Delage, A.J.Chulia, M.Rigaud: Characterization of ursolic acid as a lipoxygenase and cyclooxygenase inhibitor using macrophages, platelets and differentiated HL60 leukemic cells. FEBS Lett 299:213-217, 1992.

Novotny L., A. Vachalkova, D.Biggs: Ursolic acid: an antitumorigenic and chemopreventive activity. Neoplasma 48:241-246, 2001.

Olukoga A., D. Donaldson: Liquorice and its health implications. J R Soc Health 120:83-89, 2000.

Patočka J: Antiinflammatory triterpenoids from mysterious muscroom Ganoderma lucidum and their potential 
possibility in modern medicine. Acta Medica (Hradec Kralove) 42:123-125, 1999.

Pisha E., H.Chai, I.S.Lee, T.E.Chagwedera, N.R.Farnsworth, G.A.Cordell, C.W.Beecher, H.H.Fong, A.D.Kinghorn, D.M.Brown et al.: Discovery of betulinic acid as a selective inhibitor of human melanoma that functions by induction of apoptosis. Nat Med 1:1046-1051, 1995.

Rajic A., G. Kweifio-Okai, T. Macrides, R.M.Sandeman, D.S.Chandler, G.M.Polya: Inhibition of serine proteases by anti-inflammatory triterpenoids. Planta Med 66:206210,2000

Recio M.C., R.M.Giner, S.Manez, J.L.Rios: Structural requirements for the anti-inflammatory activity of natural triterpenoids. Planta Med 61:182-185, 1995.

Rieber M., M. Strasberg Rieber: Induction of p53 without increase in p21WAF1 in betulinic acid-mediated cell death is preferential for human metastatic melanoma. DNA Cell Biol 17:399-406, 1998.

Salti G.I., J.V.Kichina, T.K.Das Gupta, S. Uddin, L.Bratescu, J.M.Pezzuto, R.G.Mehta, A.I.Constantinou : Betulinic acid reduces ultraviolet-C-induced DNA breakage in congenital melanocytic naeval cells: evidence for a potential role as a chemopreventive agent. Melanoma Res 11:99-104, 2001.

Schmidt M.L., K.L.Kuzmanoff, L.Ling-Indeck, J.M.Pezzuto : Betulinic acid induces apoptosis in human neuroblastoma cell lines. Eur J Cancer 33:2007-2010, 1997.

Selzer E., E. Pimentel, V. Wacheck, W.Schlegel, H.Pehamberger, B.Jansen, R.Kodym: Effects of betulinic acid alone and in combination with irradiation in human melanoma cells. J Invest Dermatol 114:935-940, 2000.
Simoes C.M., M.Amoros, L.Girre: Mechanism of antiviral activity of triterpenoid saponins. Phytother Res 13:323328, 1999.

Singh G.B., S.Singh, S.Bani, B.D.Gupta, S.K.Banerjee: Antiinflammatory activity of oleanolic acid in rats and mice. J Pharm Pharmacol 44:456-458, 1992.

Sirtori C.R. Aescin: pharmacology, pharmacokinetics and therapeutic profile. Pharmacol Res 44:183-193, 2001.

Soler F., C. Poujade, M. Evers, J. C. Carry, Y.Henin, A.Bousseau, T. Huet, R.Pauwels, E. De Clercq, J.F.Mayaux, J.B. Le Pecq, N. Dereu: Betulinic acid derivatives: a new class of specific inhibitors of human immunodeficiency virus type 1 entry. J Med Chem 39:1069-1083, 1996.

Subhadhirasakul S., H.Takayama, F.M.Kitajima, N.F.Aimi: Triterpenoids from Thai medicinal plant, Willughbeia firma. Natural Med 54: 155-157, 2000.

Szakiel A., I.Wasiukiewicz, W.Janiszowska: Metabolism of [3-3H]oleanolic acid in the isolated Calendula officinalis leaf cells and transport of the synthesized glycosides to the cell wall and the extracellular space. Acta Biochim Pol 42:25-29, 1995.

Takeoka G., L. Dao, R. Teranishi, R.Wong, S.Flessa, L.Harden, R.Edwards: Identification of three triterpenoids in almond hulls. J Agric Food Chem 48:3437-3439, 2000.

Zuco V., R. Supino, S.C.Righetti, L.Cleris, E.Marchesi, C.Gambacorti-Passerini, F.Formelli: Selective cytotoxicity of betulinic acid on tumor cell lines, but not on normal cells. Cancer Lett 175:17-25, 2002.

\section{Address:}

Jiří Patočka, Katedra toxikologie, Vojenská lékařská akademie, Třebešská 1575, 50001 Hradec Králové, Czech Republic; patocka@pmfhk.cz 